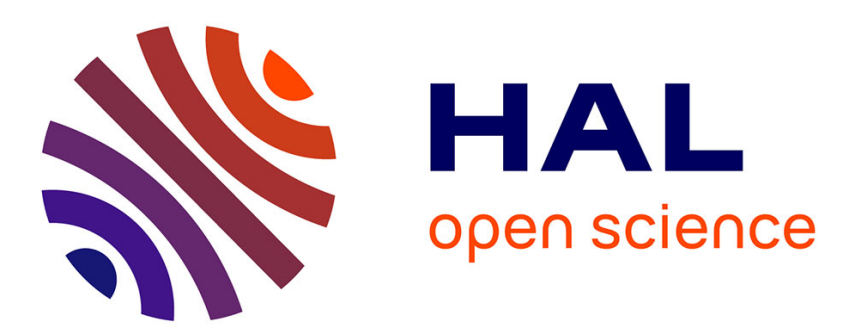

\title{
A Low-profile Ultra-wideband LTCC Based Microstrip Antenna for Millimeter-wave Applications under 100 $\mathrm{GHz}$
}

\author{
D Khezzar, D Khedrouche, A T Denidni, Camilla Kärnfelt
}

\section{- To cite this version:}

D Khezzar, D Khedrouche, A T Denidni, Camilla Kärnfelt. A Low-profile Ultra-wideband LTCC Based Microstrip Antenna for Millimeter-wave Applications under $100 \mathrm{GHz}$. Journal of Nano and Electronic Physics, 2020, 12 (4), 10.21272/jnep.12(4).04009 . hal-02946960

\section{HAL Id: hal-02946960 https://imt-atlantique.hal.science/hal-02946960}

Submitted on 29 Sep 2020

HAL is a multi-disciplinary open access archive for the deposit and dissemination of scientific research documents, whether they are published or not. The documents may come from teaching and research institutions in France or abroad, or from public or private research centers.
L'archive ouverte pluridisciplinaire HAL, est destinée au dépôt et à la diffusion de documents scientifiques de niveau recherche, publiés ou non, émanant des établissements d'enseignement et de recherche français ou étrangers, des laboratoires publics ou privés. 


\title{
A Low-profile Ultra-wideband LTCC Based Microstrip Antenna for Millimeter-wave Applications under $100 \mathrm{GHz}$
}

\author{
D. Khezzar ${ }^{1, *}$, D. Khedrouche ${ }^{1, \dagger}$, A.T. Denidni²,‡, C. Kärnfeltt,\$ \\ ${ }^{1}$ Laboratoire d'Analyse des Signaux et Systèmes, Département d'Electronique, Université Mohamed Boudiaf \\ de M'sila, BP.166, Route Ichebilia, 28000 M'sila, Algeria \\ 2 Centre for Energy, Materials and Telecommunication, National Institute of Scientific Research (INRS), \\ Montreal, Quebec, Canada \\ ${ }^{3}$ IMT Atlantique, Lab-STICC, UMR CNRS 6285, F-29238 Brest, France
}

(Received 04 June 2020; revised manuscript received 15 August 2020; published online 25 August 2020)

\begin{abstract}
In this paper, a low profile ultra-wideband microstrip antenna is proposed for millimeter wave applications below $100 \mathrm{GHz}$ to meet the demands of high data rates in the future wireless communication systems. The proposed antenna consists of a non-uniform hexagon shape radiating element on the top of 13 th layer of ceramic. The proposed antenna geometry is designed using Low Temperature Co-fired Ceramic (LTCC) technology for 3D multilayer vertical integration. HFSS and CST Studio are used for design and simulation of this ultra-wideband antenna. This antenna covers a bandwidth of $33.5 \mathrm{GHz}$ that ranges from $62.5 \mathrm{GHz}$ to more than $96 \mathrm{GHz}$ with a peak gain of $5.7 \mathrm{dBi}$, stable radiation pattern across the bandwidth, and compact size of $3.16 \times 3.2 \mathrm{~mm}^{2}$. The limitation of the narrow band in microstrip antenna is successfully dispensed by increasing the matching impedance bandwidth to more than $40 \%$. The proposed microstrip antenna is very useful for modern wireless communication systems because of its capability of covering a very wide bandwidth with favorable impedance matching and a stable radiation pattern at the considered frequency range. This antenna has another advantage in terms of the ability to be directly integrated with other RF chips using LTCC multilayer technology.
\end{abstract}

Keywords: Ultra-wideband, Microstrip antenna, LTCC, Multilayer, mm-waves.

DOI: 10.21272/jnep.12(4).04009

PACS numbers: 84.40.Ba, 84.40.Ua

\section{INTRODUCTION}

After the increased demand of broader bandwidth, the interest toward the millimeter-wave spectrum at 30 to $300 \mathrm{GHz}$ has considerably increased in the past few years $[1,2]$. The focus on ultra-wideband technology is due to the ability of this technology of transmitting a large amount of data with low transmission power in the short-range indoor and outdoor wireless communications [3]. The antenna is one of the most important components of the communication system and plays a critical role to take advantage of this spectrum, and many researchers have been working on improving the antenna response to give better performances and efficiency of the radiating element design [4]. The narrow bandwidth is a critical drawback in high data rate systems; antennas with ultra-wide bandwidths (UWB) permit to overcome this disadvantage because of their ability to support multiple bands, and several researchers have performed significant works in designing UWB antennas over the last two decades [5, 6].

Ultra-wideband technology is defined as the communication technology that occupies a bandwidth of more than $20 \%$ of its center frequency [7]. A wide variety of antenna designs for various applications have been proposed in the literature. However, the design and implementation of the UWB antennas themselves present many challenges. To support the characteristics of UWB technology, the UWB antenna should keep favorable impedance matching and radiation pattern at a broad frequency range [8]. Microstrip antennas offer very attractive characteristics such as their small size, lightness, low cost, etc. [9-11]. Based on printed technology, this type of antenna has a wide range of applications in wireless communication, in particular in mobile communication devices [12]. However, microstrip patch antennas have a low gain and a very narrow operating bandwidth which is generally less than $5 \%$ [13]. To design this antenna, Balanis defined a set of design rules and guidelines for microstrip patch antennas, which can be modified and optimized according to the intended use $[14,15]$.

The integration method of UWB antenna with the wireless module is very distinguishable criterion compared to microwave antennas in the preexisting wireless communication systems. At millimeter waves, there are generally two approaches for antenna packaging, namely the system on chip and system in package. LTCC offers an attractive solution for easy, compact and high flexibility for multilayer vertical integration topology $[16,17]$. The LTCC technology has been actively studied for millimeter wave antenna and package solutions. It offers low conductor and dielectric losses and high design freedom through the high possible number of layers, easy integration, flexible via holes distribution, and is mechanically strong [18, 19]. For such reasons, it is preferred over high-volume PCBs for

\footnotetext{
*djamel.khezzar@univ-msila.dz

$\dagger$ djamel.khedrouche@univ-msila.dz

‡denidni@emt.inrs.ca

§camilla.karnfelt@imt-atlantique.fr
} 
high performance millimeter antenna design.

In the rest of this paper, we focus on developing an UWB microstrip antenna realized in LTCC technology operating in the millimeter frequencies with acceptable performances to meet the demands of high data rate in future wireless communication systems. The geometry of the proposed design is described in section 2 of this paper, using the indicated technology, which inherently uses substrates with dielectric permittivity of 4.11 and strip line feeding structure at $\mathrm{mm}$-wave frequencies that are the two major challenges for achieving an ultra wideband operation. The simulation results, obtained using HFSS and CST Studio, show that these challenges have been successfully overcome and wideband characteristics are achieved with this simplified antenna design as presented in section 3 . Section 4 concludes the paper.

\section{ANTENNA DESIGN}

The geometry of the proposed ultra large band antenna is shown in Fig. 1. This geometry is designed based on LTCC multilayer technology for vertical integration, the proposed antenna consists of a non-uniform hexagon patch placed on the top of 13th layer of ceramic, and is considered as the main radiating element. This multilayer microstrip antenna is fed by the $50 \mathrm{Ohm}$ strip line in the 8th layer. The strip line is connected to the radiating element using a vertical probe which allows the use of a thicker substrate in order to increase the antenna bandwidth. The strip line and the radiating element are separated by the top slotted ground in the 9th layer. The proposed UWB antenna has dimensions of $3.16 \times 3.2 \mathrm{~mm}^{2}$ printed on LTCC dielectric substrate with relative permittivity and loss tangent of 4.11 and 0.008 , respectively. The antenna geometry has been developed respecting the LTCC technology design rules. The layer thickness is $0.75 \mu \mathrm{m}$ for each tape after firing and the metal layer is $6 \mu \mathrm{m}$ thick. More LTCC design properties are presented in Table 1.

The dimensions of the radiating element are calculated using a MATLAB algorithm based on the transmission line model [14]. In the general case, the antenna length is equal to half-wavelength at the operating frequency. By using the transmission line model, the effective length must be calculated taking into consideration the non-homogeneity between the two media of propagation which are the air and the dielectric. Due to the inaccurate results in terms of antenna dimensions using the transmission line model, a massive parametric study is applied in order to fix the desired frequency range of operation and to optimize the other antenna characteristics. Hence, the obtained outputs of length and width of this algorithm are kept as the initial values of parametric study [20]. Note that the parametric study permits more than three-dimensional parameters to be varied while the other parameters are fixed in a constant value. First, the parametric study was applied by considering a rectangular patch in order to optimize the length and the width of the radiating element. Then, the length of the strip line was optimized to determine the best excitation position. Next, the corners of the radiating elements were truncated and another parametric study was applied in order to optimize the response of this UWB antenna by looking for the wider

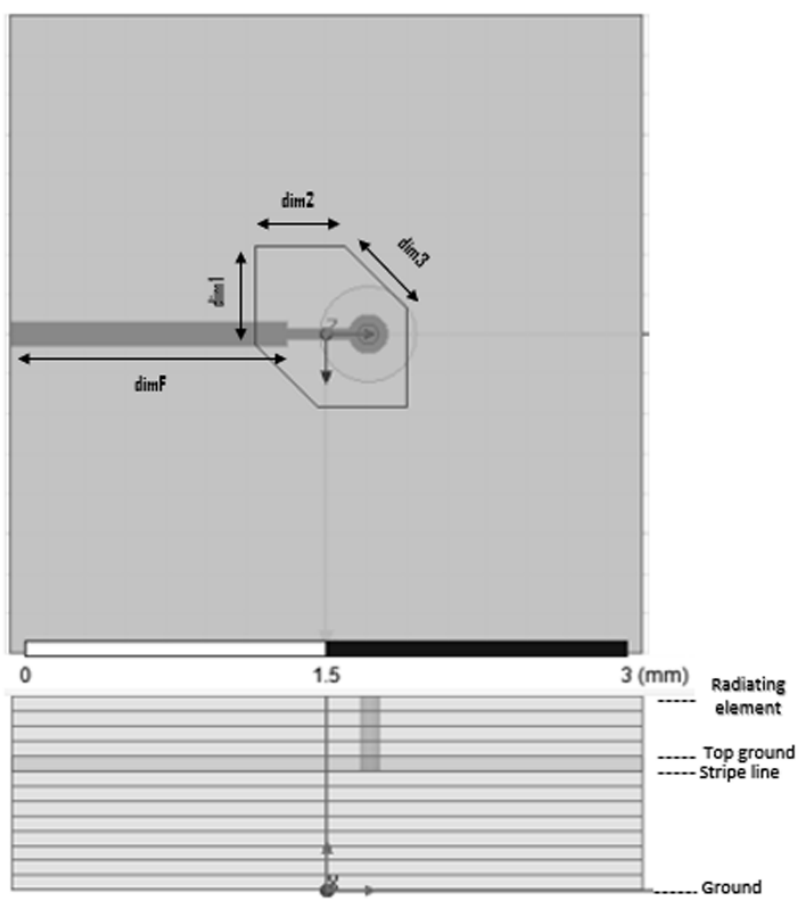

Fig. 1 - Antenna geometry

bandwidth, the higher gain, and the best impedance matching. Thus, the applied parametric study includes all dimensional parameters of the antenna. Note that this parametric optimization is repeated until reaching an optimal solution that meets the design requirements in terms of the antenna performance previously indicated. The final optimized dimensions are presented in Table 2. The antenna corners are truncated in order to give more design freedom to the optimization through the parametric study by increasing the number of parameters to be optimized. The goal of this geometry, as an UWB antenna, is to make this antenna capable of receiving all frequencies at the same time instant by increasing its fractional bandwidth. Besides, the antenna to be manufactured in LTCC technology can be directly and easily integrated with RF chips on LTCC substrates. Thus, the proposed antenna is simplified in order to reduce fabrication cost and to facilitate the manufacturing process.

Table 1 - LTCC design criteria

\begin{tabular}{|c|c|c|c|}
\hline $\begin{array}{c}\text { Dielectric per- } \\
\text { mittivity }\end{array}$ & $\varepsilon_{r}=4.11$ & Conductor type & Gold \\
\hline Loss tangent & $\tan \delta=0.008$ & $\begin{array}{c}\text { Number of } \\
\text { layers above } \\
\text { the strip line } \\
\text { ground to the } \\
\text { antenna } \\
\text { radiating ele- } \\
\text { ment }\end{array}$ & NL $=4$ \\
\hline $\begin{array}{c}\text { Layer } \\
\text { thickness }\end{array}$ & $75 \mu \mathrm{m}$ & $\begin{array}{c}\text { Number of } \\
\text { layers } \\
\text { between the } \\
\text { strip line and } \\
\text { the top ground } \\
\text { layer }\end{array}$ & $\mathrm{NL}=1$ \\
\hline $\begin{array}{c}\text { Metal layer } \\
\text { thickness }\end{array}$ & $9 \mu \mathrm{m}$ & $\begin{array}{c}\text { Number of } \\
\text { layers below } \\
\text { the strip line }\end{array}$ & $\mathrm{NL}=8$ \\
\hline
\end{tabular}


Table 2 - Antenna parameters

\begin{tabular}{|c|c|c|}
\hline Parameter & \multicolumn{2}{|c|}{ Length } \\
\hline $\operatorname{dim} 1$ & $0.49(\mathrm{~mm})$ & $0.129 \lambda_{0}$ \\
\hline $\operatorname{dim} 2$ & $0.45(\mathrm{~mm})$ & $0.119 \lambda_{0}$ \\
\hline $\operatorname{dim} 3$ & $0.438(\mathrm{~mm})$ & $0.115 \lambda_{0}$ \\
\hline $\operatorname{dimF}$ & $1.39(\mathrm{~mm})$ & $0.366 \lambda_{0}$ \\
\hline Probe radius & $0.05(\mathrm{~mm})$ & $0.013 \lambda_{0}$ \\
\hline Probe height & $0.5009(\mathrm{~mm})$ & $0.132 \lambda_{0}$ \\
\hline Slot radius & $0.24(\mathrm{~mm})$ & $0.063 \lambda_{0}$ \\
\hline
\end{tabular}

\section{SIMULATED RESULTS}

Two software are used for simulation of this UWB microstrip antenna, HFSS (High Frequency Structure Simulator) and CST Studio. The two used software enable fast and accurate analysis of high frequency (HF) devices such as filters, couplers, antennas, planar and multilayer structures. Fig. 2 shows the obtained surface current distribution of the designed UWB antenna at different frequencies $66 \mathrm{GHz}, 75 \mathrm{GHz}, 85 \mathrm{GHz}$ and $93 \mathrm{GHz}$. This figure shows that the high magnitude of the surface current is around the feeding probe position, and is minimal at the edges of the radiating element. Since the voltage is inverse to the current, the low magnitude of the current at the radiation edges means that the voltage is at its peak value and the corresponding corners are considered as the radiating edges of the microstrip UWB antenna.
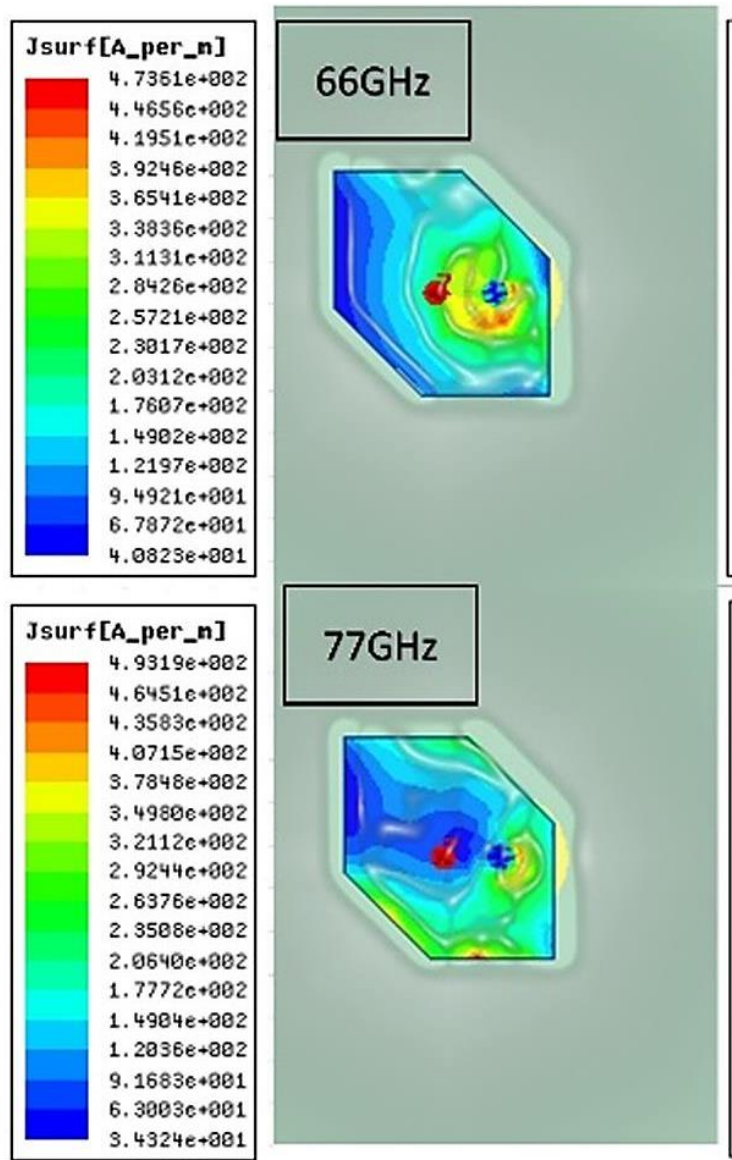

Fig. 3 shows the obtained return loss of the proposed antenna. The related bandwidth in this plot is defined as the frequency range where the return loss is better than $10 \mathrm{~dB}$. According to this obtained curve, a bandwidth of more than $33.5 \mathrm{GHz}$ is achieved for this designed antenna, that ranges from $62.5 \mathrm{GHz}$ to more than $96 \mathrm{GHz}$ in the two used software. This antenna covers a very large bandwidth in millimeter wave spectrum below $100 \mathrm{GHz}$. This return loss graph suggests that there is good impedance matching at the considered bandwidth as it ranges from $-12 \mathrm{~dB}$ to $-28 \mathrm{~dB}$. Two main resonance frequencies are observed at $65.7 \mathrm{GHz}$ and $83.4 \mathrm{GHz}$. One of the serious limitations of this microstrip antenna was its narrow bandwidth characteristics compared to UWB Technology needs. The limitation is successfully dispensed by increasing the matching impedance bandwidth to more than $40 \%$. A slight difference is observed between the two graphs due to the use of two different simulation solver types.

The difference between two solvers is less remarkable in VSWR characteristics of this antenna as illustrated in Fig. 4. According to the obtained curves of the VSWR at this figure, good impedance matching along with the whole considered frequency bandwidth, as it is noted less than 2. The more VSWR curve is closer to 1.0 , the less power is reflected from the antenna. This points how well the antenna terminal input impedance is matched to the characteristic impedance of the transmission line.

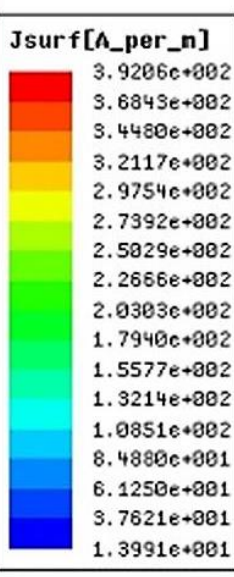

Jsurf [A_per_m] $5.5183 c+282$ $5.1743 e+082$ 4. $83838+082$ 4. $4863 c+982$ 4. $2423 c+282$ 3. $7983 e+082$ 3. $4543 e+082$ 3. $1103 e+002$ 2. $7663 c+202$ 2. $4223 c+802$ $2.0782 e+082$ 1. $7342 e+802$ 1. $3902 c+902$ $1.0482 c+802$ $7.0221 e+881$ $3.5820 e+001$ 1. $4193 c+900$

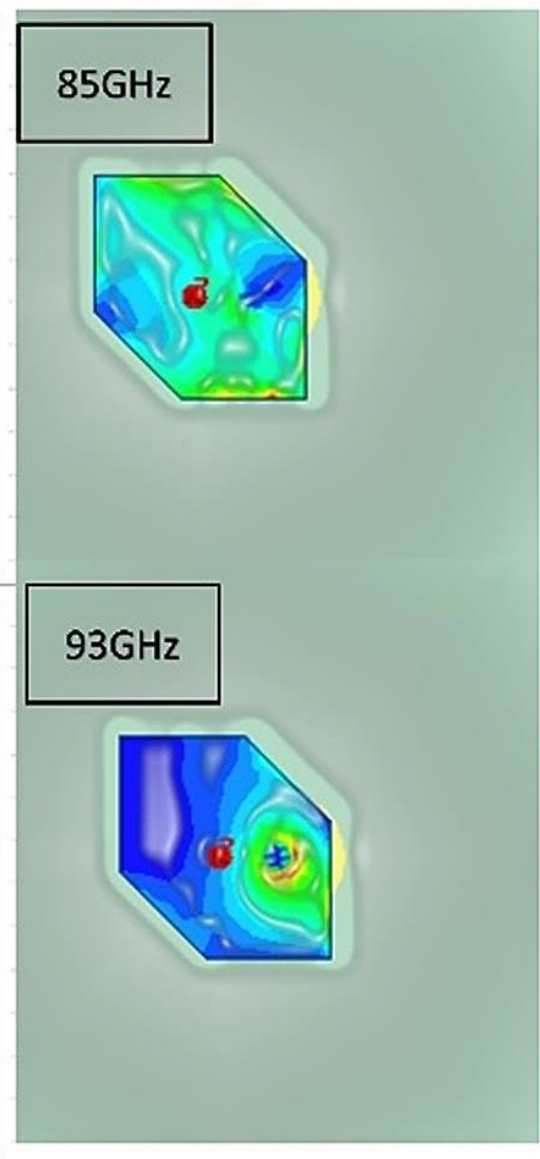

Fig. 2 - Surface current distribution 


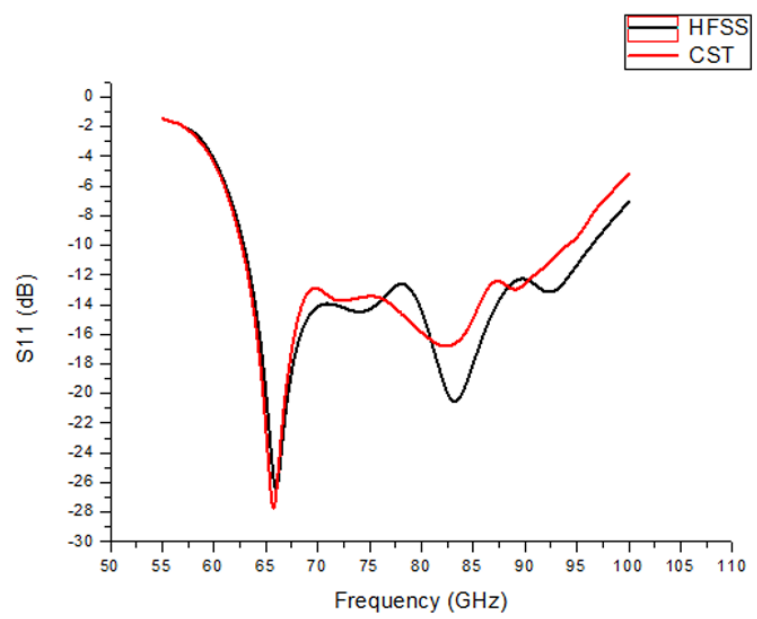

Fig. 3 - Antenna return loss

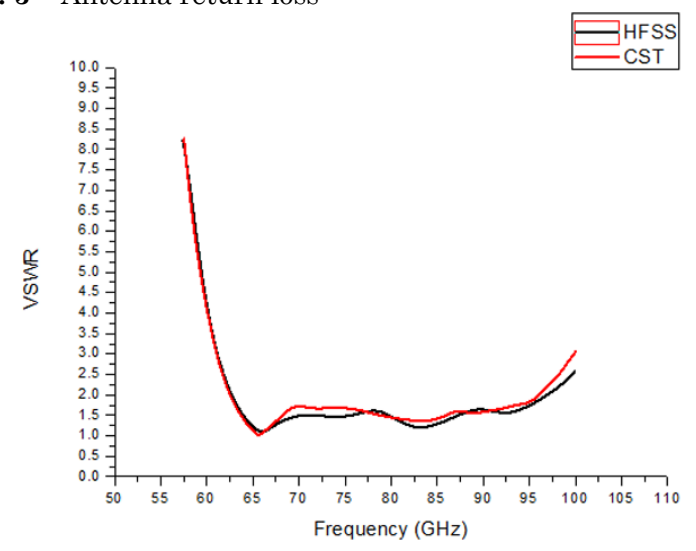

Fig. 4 - VSWR

The imaginary and real parts of the antenna impedance are shown in Fig. 5 and Fig. 6, respectively. It is observed that at the frequency range of interest, the antenna input resistance is equal or close to $50 \mathrm{ohms}$ which means the power that arrives to the antenna is radiated away. Otherwise, the received power is absorbed by the antenna. The imaginary part of the input impedance represents the power which is stored in the near field of the radiator. This power is not considered as a radiated power. An antenna with zero reactance and real input impedance (zero imaginary part) is considered to be resonant at the corresponding frequency. The obtained results of the antenna reactance (imaginary part of the antenna input

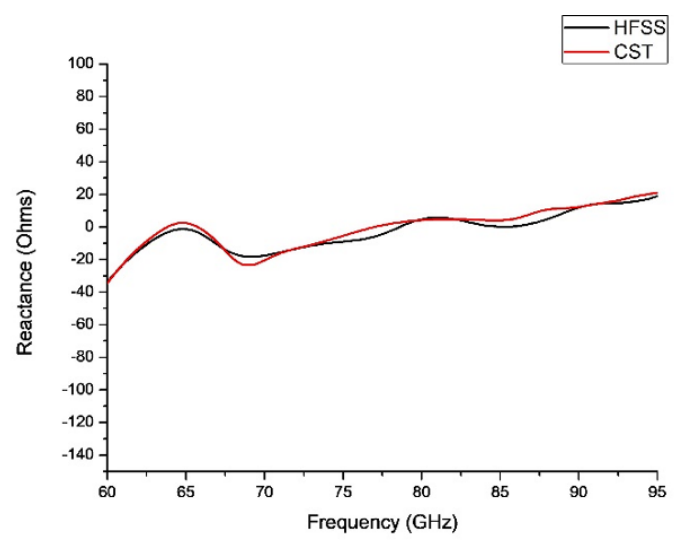

Fig. 5 - Antenna reactance

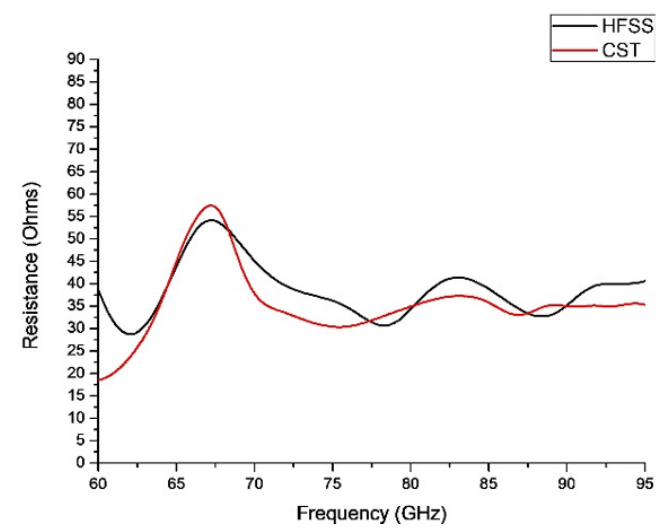

Fig. 6 - Antenna resistance

impedance) and resistance (real part of the antenna input impedance) show good impedance matching at the considered frequency spectrum.

Fig. 7 shows the obtained plots of gain as a function of frequency in the two used software programs. The antenna gain demonstrates how well the antenna converts input power into radio waves. The obtained gain is acceptable for the single antenna in this range of spectrum because the radiating element becomes too small as its size needs to be scaled to the wavelength. The performance in terms of gain for this antenna has a maximum gain of about $5.7 \mathrm{dBi}$.

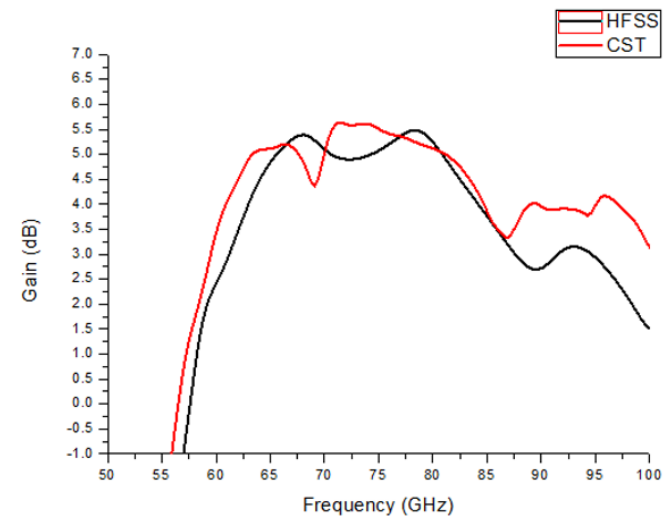

Fig. 7 - Antenna gain

Fig. 8 shows the obtained polar radiation pattern of this proposed antenna in order to check the stability of the radiation pattern of this designed UWB antenna in the considered frequency bandwidth. The $3 \mathrm{D}$ radiation patterns at different frequencies $66 \mathrm{GHz}, 75 \mathrm{GHz}$, $85 \mathrm{GHz}$, and $93 \mathrm{GHz}$ are illustrated in Fig. 9. According to this figure, the antenna presents another important factor of performance in terms of stability of the radiation pattern across the bandwidth. The proposed UWB antenna has omnidirectional radiation with maximum radiation on the $Z$-axis. These obtained results make this antenna very attractive for use in practical devices.

\section{CONCLUSIONS}

In this paper, a low-profile ultra-wideband microstrip antenna is proposed based on the LTCC technology. The obtained results have been verified using HFSS and CST Studio. This antenna provides a wide 


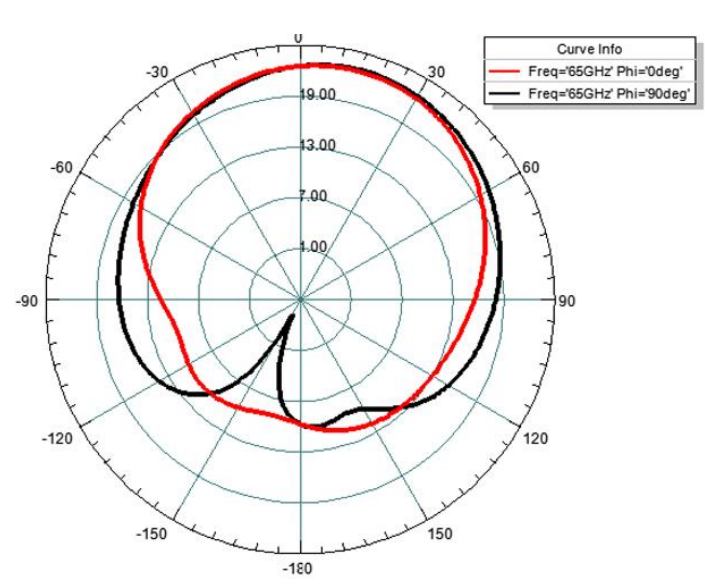

Fig. 8 - Polar radiation pattern for $E$ plan and $H$ plan

bandwidth in millimeter wave spectrum under $100 \mathrm{GHz}$ ranging from $62.5 \mathrm{GHz}$ to more than $96 \mathrm{GHz}$ in the two used software. The obtained results suggest that there is good impedance matching at the considered bandwidth with a peak gain of $5.7 \mathrm{dBi}$. A good antenna behavior is observed in terms of the antenna radiation pattern and its response stability in the considered spectrum. This antenna has another advantage in terms of the ability to be directly integrated with other RF chips

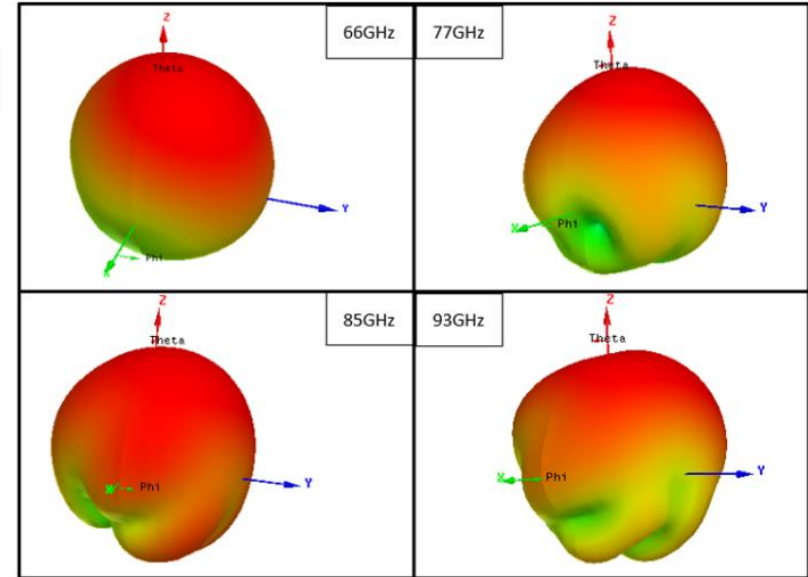

Fig. 9 - 3D radiation pattern produced at 66, 77, 85 and $93 \mathrm{GHz}$ using LTCC multilayer technology. These factors make this proposed antenna a good candidate to support the UWB technology needs.

\section{ACKNOWLEDGEMENTS}

This work was supported by the Algerian Ministry of Higher Education and Scientific Research via funding through the PRFU project No. A25N01UN280120180001.

\title{
REFERENCES
}

1. M. Li, K.M. Luk, IEEE T. Anten. Propag. 63 No 7, 3276 (2015).

2. Y. Al-Alem, A.A. Kishk, 2018 IEEE International Symposium on Antennas and Propagation \& USNC/URSI National Radio Science Meeting, art. No 8608172, 1693 (IEEE: 2018).

3. D.R. Johnson, L. Volakis, Antenna Engineering Handbook, (New York: McGraw-Hill: 2007).

4. S. Kundu, A. Chatterjee, S.K. Jana, S.K. Parui. Radioengineering 27 No 1, 448 (2018).

5. S.M. Moghaddam, J. Yang, A.A. Glazunov. 2017 International Symposium on Antennas and Propagation (ISAP), art. No 8228955, 1 (IEEE: 2017).

6. T. Saeidi, I. Ismail, W.P. Wen, A.R.H. Alhawari, A. Mohammadi, Int. J. Anten. Propag. 2019, 7918765 (2019).

7. J. Schneider, J. Gamec, Acta Electrotechnica et Informatica 14 No 2, 54 (2014).

8. M. Du, J. Xu, X. Ding, J.P. Cao, J.H. Deng, Y.L. Dong, Radioengineering 27 No 2, 455 (2018).

9. P. Shirvani, H. Shirzadfar, J. Nano- Electron. Phys. 8 No 3, 03028 (2016).

10. S. Djidel, M. Bouamar, D. Khedrouche, World J. Eng. 15 No 1 , 330 (2018).

11. J.P. Shinde, R. Kumar, M.D. Uplane, Wireless Personal Commun. 75 No 2, 843 (2014).

12. A. Bondarik, D. Sjoberg, 2015 IEEE-APS Topical Conference on Antennas and Propagation in Wireless Communications (APWC), art. No 7300200, 1202 (IEEE: 2015).

13. K.D. Xu, H. Xu, Y. Liu, J. Li, Q.H. Liu, IEEE Access 6, 11624 (2018).

14. C.A. Balanis, Antenna Theory Analysis And Design (New Jersey: John Wiley \& Sons: 2005).

15. K.S. Chin, W. Jiang, W. Che, C.C. Chang, H. Jin, IEEE T. Anten. Propag. 62 No1, 174 (2014).

16. H. Bong, M. Jeong, N. Hussain, S. Rhee, S. Gil, N. Kim, Microwave Opt. Technol. Lett. 61 No 5, 1295 (2019).

17. U. Ullah, N. Mahyuddin, Z. Arifin, M.Z. Abdullah, A. Marzuki, IEEE Anten. Propag. Magaz. 57 No 2, 241 (2015).

18. M. Mosalanejad, S. Brebels, C. Soens, I. Ocket, G.A.E. Vandenbosch, Prog. Electromagn. Res. 158, 89 (2017).

19. B. Zhang, H. Gulan, T. Zwick, Y. Li, U. Oderfalt, F. Carlsson, H. Zirath, IEEE T. Compon., Packag. Manufactur. Technol. 5 No 8, 1060 (2015).

20. Bouttout, Y. Bentrcia, S. Benkouda, T. Fortaki, J. Nano- Electron. Phys. 10 No 4, 04004 (2018).

\section{Низькопрофільна ультраширокосмугова мікросмужкова антена на основі LTCC для додатків міліметрового діапазону до 100 ГГц}

\author{
D. Khezzar ${ }^{1}$, D. Khedrouche ${ }^{1}$, A.T. Denidni² ${ }^{2}$ C. Kärnfelt ${ }^{3}$
}

${ }^{1}$ Laboratoire d'Analyse des Signaux et Systèmes, Département d'Electronique, Université Mohamed Boudiaf de M'sila, BP.166, Route Ichebilia, 28000 M'sila, Algeria

2 Centre for Energy, Materials and Telecommunication, National Institute of Scientific Research (INRS),

Montreal, Quebec, Canada

${ }^{3}$ IMT Atlantique, Lab-STICC, UMR CNRS 6285, F-29238 Brest, France 
У роботі запропонована низькопрофільна ультраширокосмугова мікросмужкова антена для додатків міліметрового діапазону нижче 100 ГГц щоб задовільнити потреби високих швидкостей передачі даних у майбутніх бездротових системах зв'язку. Запропонована антена складаеться з неоднорідного шестикутного випромінюючого елементу зверху 13-го шару кераміки. Геометрія запропонованої антени розроблена з використанням технології низькотемпературної Со-кераміки (LTCC) для 3D багатошарової вертикальної інтеграції. HFSS та CST Studio використовуються для проектування та моделювання ціеї ультраширокосмугової антени. Ця антена охоплюе діапазон частот 33,5 ГГц, який варіюеться від 62,5 ГГц до більше ніж 96 ГГц з піковим посиленням 5,7 дБі, мае стабільну діаграму спрямованості по всьому діапазону частот та компактний розмір $3,16 \times 3,2$ мм² $^{2}$ Обмеження вузького діапазону в мікросмужковій антені успішно здійснюеться шляхом збільшення ширини смуги пропускання понад $40 \%$. Запропонована мікросмужкова антена є дуже корисною для сучасних бездротових систем зв'язку через її здатність охоплювати дуже широкий діапазон пропускання із сприятливим узгодженням імпедансів та стабільною діаграмою спрямованості у розглянутому діапазоні частот. Ця антена мае ще одну перевагу в плані можливості бути безпосередньо інтегрованою з іншими RF мікросхемами за допомогою багатошарової технології LTCC.

Ключові слова: Ультраширока смуга, Мікросмужкова антена, LTCC, Мультишар, мм-хвилі. 